\title{
Resiliensi dan Kesejahteraan Subjektif Anak Didik Lembaga Pembinaaan Khusus Anak (LPKA)
}

\author{
Ajeng Rintan Septiani, Sri Maslihah, M. Ariez Musthofa \\ Departemen Psikologi, Fakultas Ilmu Pendidikan, Universitas Pendidikan Indonesia, Bandung
}

\begin{abstract}
Abstrak. Kesejahteraan subjektif merupakan bentuk penilaian dan pandangan terhadap peristiwa dalam hidup yang juga sangat penting bagi anak didik LPKA, mengingat kondisi kehidupan yang mereka alami selama masa binaan cenderung berbeda dibandingkan dengan anak lainnya. Penelitian kesejahteraan subjektif anak didik di LPKA ini dilakukan untuk mendapatkan data terkait kesejahteraan subjektif anak didik LPKA yang dipengaruhi oleh resiliensi dan mengetahui pengaruhnya pada setiap domain. Penelitian dilakukan pada 83 anak didik pada rentang usia dari 12-18 tahun yang berstatus narapidana, dengan menggunakan pendekatan kuantitatif dan metode pengambilan data menggunakan kuesioner Skala Resiliensi hasil pengembangan Reivich dan Shatte (2002) serta alat ukur Kesejahteraan Psikologis Integratif hasil pengembangan Maslihah, et al. (2017). Hasil penelitian menunjukkan bahwa resiliensi diketahui dapat memengaruhi kesejahteraan subjektif anak didik LPKA $(\mathrm{p}<.05)$, pengaruh tersebut juga dapat dilihat melalui domain akademik, organisasi, interaksi sosial, serta kegiatan. Kesejahteraan subjektif anak didik LPKA dapat ditingkatkan dengan adanya resiliensi.
\end{abstract}

Kata Kunci: anak didik, kesejahteraan subjektif, Lembaga Pembinaaan Khusus Anak (LPKA), resiliensi

\section{Resilience and Subjective Well-Being among Imprisoned Children}

Abstract. Subjective well-being is a form of evaluation and reflection towards life events which are also very important for imprisoned children in Lembaga Pembinaan Khusus Anak (LPKA, a special jail for imprisoned children), since they had a different life from the ordinary children. Research of subjective wellbeing on child prisoners aims to gather data about subjective wellbeing of child prisoners in LPKA by resilience and to know the effect on each domains. The research involves 83 child prisoners in an age range of 12-18. This quantitative research uses Resilience Scale questionnaire by Reivich and Shatte (2002) and Integrative Psychological WellBeing measurements by Maslihah, et al,. (2017). It points out that resilience significantly affects subjective wellbeing $(\mathrm{p}<.05)$, in many aspects such as academic, organization, association, and activity. Subjective wellbeing in child prisoners can be improved by the resilience.

Keywords: child prisoners, Lembaga Pembinaan Khusus Anak, resilience, subjective well being

Korespondensi: Ajeng Rintan Septiani. Email: ajengrintan@student.upi.edu 
Fenomena tentang kasus anak yang berhadapan dengan hukum terus meningkat dari tahun ke tahun (Yulianto \& Ernis, 2016). Selama tahun 2018, jumlah pengaduan terhadap kasus anak berhadapan dengan hukum mengalami peningkatan dari jumlah 3,849 pada tahun 2017 (Setyawan, 2017) hingga menjadi 4,885. Peraturan terkait kasus anak berhadapan dengan hukum ini tercantum dalam UU No.11 tahun 2012 tentang Sistem Peradilan Pidana Anak yang menyebutkan bahwa anak yang berhadapan dengan hukum adalah anak yang berkonflik dengan hukum, anak korban tindak pidana, dan anak yang menjadi saksi tindak pidana. Berdasarkan UU No.11 tahun 2012 juga diterangkan lebih lanjut tentang pengertian anak yang berkonflik dengan hukum yakni merupakan anak yang berusia 12 tahun namun belum berusia 18 tahun yang diduga melakukan tindak pidana. Sebagai tindak lanjutnya, UU SPPA No.11 tahun 2012 menyebutkan bahwa seorang anak yang melakukan tindak pidana tetap berhak dilindungi secara hukum agar responden tetap bisa bertumbuh dan berkembang dengan mendapatkan pembinaan serta pendidikan yang layak di lembaga pemasyarakatan tempat responden menjalani hukuman (Ariani, 2014). Pernyataan tersebut diwujudkan dalam bentuk kegiatan pembinaan yang ada di dalam lembaga pemasyarakatan yang dikhususkan bagi anak di bawah umur (Jiwantari et al., 2017). Di Indonesia, lembaga pemasyarakatan yang memiliki fungsi untuk menjalankan hukuman dengan menerapkan sistem pembinaan dan pendidikan yang dikhususkan untuk anak disebut dengan Lembaga Pembinaan Khusus Anak (LPKA) (Jiwantari et al., 2017). Sampai pada bulan Maret 2019 anak yang berstatus sebagai narapidana di Indonesia tercatat sejumlah 2,263 dan 922 anak lainnya berstatus sebagai tahanan (Kemenkumham, 2019). Di LPKA Kelas II Bandung sendiri diketahui terdapat 138 anak didik (selanjutnya disingkat dengan andik) dengan rincian jenis kejahatan 35\% merupakan kasus pelanggaran terhadap perlindungan anak, 31\% kasus pelanggaran terhadap ketertiban yang didominasi oleh perkelahian antarkelompok (tawuran), 11\% kasus pembunuhan, 9\% kasus perampokan yang didominasi oleh aksi pembegalan, dan $14 \%$ lainnya merupakan jumlah dari kasus-kasus pencurian, penganiayaan, kesehatan, narkotika, serta senjata tajam (Septiani, 2019).

Anak yang dibina di LPKA atau disebut sebagai andik akan memiliki fase kehidupan yang berbeda dan masa transisi yang lebih berat jika dibandingkan dengan anak-anak lain seusia responden yang hidup bebas di luar sana (Atikasuri et al., 2018). Kondisi tersebut tentu akan memberikan dampak pada penilaian dan pemaknaan andik terhadap peristiwa dalam hidupnya atau yang disebut juga sebagai kesejahteraan subjektif (subjective well being). Kesejahteraan subjektif merupakan bentuk pemaknaan atau penilaian yang melibatkan pengelolaan emosi dalam tolak ukur kepuasan hidup (Diener \& Ryan, 2009). Melalui 
penelitiannya, Diener (2000) mengemukakan bahwa kesejahteraan subjektif merupakan bentuk evaluasi terhadap aspek kognitif dan afektif. Evaluasi dan penilaian yang dimaksud dalam kesejahteraan subjektif ini merupakan penilaian secara positif terhadap peristiwa dan pengalaman yang dapat dimaknai sebagai bentuk kepuasan hidup (Diener, 1984). Diener (1984) juga mengemukakan bahwa kesejahteraan subjektif dapat menjadi acuan mengenai standar kehidupan seperti apa yang merupakan kehidupan yang baik. Kesejahteraan subjektif andik dapat dilihat melalui pemenuhan terhadap hak-hak responden dalam mengikuti kegiatan pembinaan yang dilakukan, mulai dari pembinaan kepribadian, kemandirian, dan pendidikan (Ayu et al., 2017; Tampubolon, 2017). Kegiatan-kegiatan yang dilakukan andik membantu mengalihkan dari pikiran serta emosi negatif dan membuat responden memiliki pandangan serta sikap positif terhadap kehidupan yang dijalani di LPKA (Bajaj \& Pande, 2016; Chen et al., 2017; Maslihah, 2018). Pandangan dan sikap positif terhadap kehidupan tersebut merupakan salah satu aspek dalam kesejahteraan subjektif yang dimiliki oleh andik di LPKA (Maslihah et al., 2015). Menurut Maslihah (2017) kesejahteraan (well being) yang dimiliki andik dapat dilihat dan ditunjukkan melalui berbagai pengalaman maupun kejadian di berbagai domain kehidupan yang kemudian saling berintegrasi menjadi tolak ukur kesejahteraan subjektif. Hal tersebut sesuai dengan pernyataan Diener $(1984,2000)$ yang mengemukakan bahwa seiring berjalannya waktu, evaluasi yang dilakukan individu tidak hanya menilai kesejahteraan (well being) responden secara umum saja, tetapi juga meliputi berbagai domain yang ada dalam kehidupannya, mulai dari domain kepuasan pernikahan, pekerjaan, dan tingkat afeksi yang responden miliki, baik afeksi negatif maupun positif. Bagi andik di LPKA domain-domain yang terlibat dalam kehidupan responden selama menjalani masa binaan di LPKA adalah domain akademik yang dilihat di lingkungan sekolah, domain organisasi yang berkaitan dengan kepemimpinan dan organisasi antar-andik, domain interaksi sosial mencakup relasi dengan sesama andik serta relasi dengan petugas, dan domain kegiatan terkait dengan keterlibatan andik dengan kegiatan di luar sekolah (Maslihah, 2017).

Namun, dalam proses pembinaannya ditemukan banyak kasus akan rendahnya kesejahteraan subjektif pada andik. Di LPKA Pontianak, 6 dari 11 andik mengalami depresi dengan rincian 1 andik diketahui mengalami depresi berat, dan 5 lainnya mengalami depresi dengan frekuensi depresi ringan (Afirio \& Raharjo, 2016). Hal serupa juga ditemukan oleh Lyu et al. (2015) yang melakukan penelitian pada remaja di Penjara Taiwan yang menunjukkan prevalensi distres psikologis sebesar $44.1 \%$ dengan rincian tekanan psikologis $36.8 \%$ diketahui mengalami gangguan tidur, $34.7 \%$ mengalami depresi, dan $27.9 \%$ terlibat permusuhan. Sementara di LPKA 
Kelas II Bandung, sampai dengan April 2019 diketahui 5 dari 114 andik memiliki tingkat kecenderungan depresi yang tinggi, 29 lainnya mengalami kecemasan tinggi dengan 10 diantaranya masuk dalam kategori sangat tinggi, dan 7 lainnya memiliki tingkat stress yang tinggi (Septiani, 2019). Data penelitian tersebut menunjukkan bahwa kondisi yang menimbulkan tekanan psikologis yang dialami oleh andik dapat memberikan dampak terhadap kesejahteraan subjektif yang responden miliki. Maslihah (2017) mengungkapkan bahwa sebanyak 51\% andik di LPKA Kelas II Bandung memiliki tingkat kesejahteraan subjektif yang rendah. Hal tersebut didukung dengan pernyataan Schütz et al. (2015) dalam penelitiannya yang mengungkapkan bahwa kesejahteraan subjektif andik diketahui lebih rendah jika dibandingkan dengan kesejahteraan subjektif anak seusia responden yang tinggal di rumah. Sejalan dengan pernyataan tersebut, andik yang telah menyelesaikan masa binaannya dan sudah diperbolehkan pulang kembali ke rumah diketahui memiliki kesejahteraan subjektif yang lebih tinggi dibandingkan andik yang masih menjalani masa binaan di LPKA (de Ruigh et al., 2019).

Rendahnya tingkat kesejahteraan subjektif yang dimiliki oleh andik dapat memberikan dampak tersendiri bagi andik, baik dampak positif maupun negatif. Menurut Göcen (2019), kesejahteraan subjektif pada anak remaja di penjara dapat meningkatkan kebersyukuran dan pemaafan pada diri responden. Sementara sebagai dampak negatifnya, Coyle dan Vera (2013) mengungkapkan bahwa andik dengan tingkat kesejahteraan subjektif rendah diketahui juga mengalami stres. Hal tersebut didukung oleh penelitian Achour et al. (2019) yang menunjukkan korelasi negatif antara kesejahteraan subjektif dan stres $(p<.0001)$, dengan kata lain rendahnya kesejahteraan subjektif akan menunjukkan tingginya tingkat stres yang dialami. Hal ini dapat bersumber dari masalah kebebasan dan penyesuaian diri atas tekanan dari adanya aturan yang membatasi dan mengikat (Sholichatun, 2011). Selama menjalani masa binaan di LPKA andik juga perlu menghadapi situasi yang mengharuskan responden hidup terpisah dari keluarga, temanteman, dan aktivitas sehari-hari yang biasa responden lakukan (Agustine et al., 2018; Maslihah, 2017). Selain itu, paradigma serta prasangka buruk dari masyarakat yang akan responden hadapi ketika kembali ke lingkungan masyarakat nanti juga dapat menjadi sumber tekanan psikologis yang dialami andik (Putra et al, 2016). Menurut hasil wawancara dalam penelitian Rizki, Murad, dan Damayanti (2019), kesejahteraan subjektif yang dimiliki narapidana di Lapas Kelas IIB Kuala Simpang rendah dan jika dilihat dalam konteks konsep diri responden masih merasa gagal dalam masa remajanya. Hal ini didukung oleh pernyataan Sari dan Maryatmi (2019) yang mengungkapkan bahwa optimisme berdampak secara signifikan terhadap kesejahteraan 
subjektif yang dimiliki andik. Menurut Barczyk et al. (2014) kesejahteraan subjektif juga memiliki korelasi yang signifikan terhadap optimisme harapan di masa depan.

Penelitian terkait kesejahteraan subjektif pada andik sendiri sudah banyak dilakukan, termasuk melalui komponen kognitif (Yuniasanti \& Sahrah, 2018). Penelitian lain yang dilakukan oleh Bloem et al. (2019) menunjukkan bahwa perubahan terhadap kondisi mental andik juga turut memengaruhi tingkat kesejahteraan subjektif responden. Sementara itu, penelitian lain menyebutkan bahwa kesejahteraan subjektif dapat diprediksi oleh kemampuan dalam menghadapi keadaan sulit yang dapat menimbulkan stress, atau yang disebut juga sebagai resiliensi (Zubair et al., 2018). Pernyataan tersebut didukung oleh penelitian Kirmani et al. (2015) yang mengungkapkan bahwa resiliensi memiliki hubungan positif yang signifikan dengan kesejahteraan subjektif mahasiswa. Penelitian yang dilakukan Chen et al. (2017) juga menunjukkan bahwa resiliensi berperan terhadap tingkat kesejahteraan subjektif mahasiswa di Cina. Penelitian lain yang dilakukan Tomyn dan Weinberg (2016) di Victoria Australia juga membuktikan korelasi yang positif antara resiliensi dan kesejahteraan subjektif. Korelasi dan hubungan positif antara kesejahteraan subjektif dan resiliensi ini dapat terjadi karena resiliensi yang tinggi akan muncul jika seseorang mampu memaknai penderitaan dan kesulitan yang dihadapi sebagai suatu jalan yang akan membuat responden menjadi lebih baik (Bajaj \& Pande, 2016). Namun, sejauh ini belum ada penelitian terkait kesejahteraan subjektif pada andik LPKA yang dikaitkan dengan resiliensi. Oleh karena itu, penelitian ini bertujuan untuk melihat apakah terdapat pengaruh antara resiliensi dengan kesejahteraan subjektif yang dimiliki andik dan melihat bagaimana pengaruhnya terhadap domain kehidupan andik selama menjalani masa binaan di LPKA.

\section{Metode}

\section{Responden penelitian}

Pendekatan yang digunakan dalam penelitian ini adalah pendekatan kuantitatif dengan menggunakan analisis regresi linier sederhana untuk mengetahui pengaruh antara resiliensi sebagai variabel $\mathrm{X}$ dengan kesejahteraan subjektif sebagai variabel Y. Sementara responden yang terlibat dalam penelitian ini adalah andik di LPKA Kelas II Bandung. Andik LPKA Kelas II Bandung terbagi ke dalam dua status, yakni andik yang berstatus tahanan dan andik yang berstatus narapidana. Namun dalam penelitian ini peneliti hanya akan menyertakan andik yang berstatus narapidana sebagai responden. Hal ini dikarenakan andik yang berstatus tahanan di LPKA Kelas II Bandung merupakan andik yang belum divonis atau masih menunggu sidang sehingga andik yang berstatus tahanan belum diperkenankan untuk mengikuti kegiatan yang ada di LPKA termasuk terlibat dalam kegiatan penelitian. 
Selain itu, penelitian ini menggunakan penelitian populatif yang artinya jumlah seluruh populasi yang ada akan diikutsertakan karena jumlah populasinya yang sedikit. Diketahui pula populasi andik LPKA Kelas II Bandung berdasarkan data dari Kementrian Hukum dan Hak Asasi Manusia sampai dengan bulan September 2019 tercatat sejumlah 128 andik yang berstatus narapidana (Kemenkumham, 2019). Namun, dikarenakan keterbatasan situasi dan kondisi yang perlu disesuaikan dengan kegiatan pembinaan yang ada di LPKA Kelas II Bandung, peneliti hanya mendapatkan izin melakukan penelitian kepada 83 andik. Sementara itu, pengambilan sampel dalam penelitian ini menggunakan teknik purposive sampling karena responden yang digunakan dalam penelitian adalah responden khusus dan jumlah populasinya sedikit sehingga teknik purposive sampling ini digunakan agar seluruh populasi dapat disertakan menjadi sampel penelitian.

\section{Instrumen penelitian}

Adapun dua instrumen yang digunakan dalam penelitian ini adalah skala resiliensi dari Reivich dan Shatte (2002) dan skala kesejahteraan psikologis integratif (KPI) yang merupakan alat ukur yang dikembangkan oleh Maslihah et al. (2017) dengan dasar teori kesejahteraan subjektif yang dikemukakan oleh Diener (1984). Kedua instrumen diujicobakan terlebih dahulu kepada 89 andik Lembaga
Pembinaan Khusus Anak (LPKA) Kelas IA Tangerang. Hasil dari pengujian alat ukur tersebut diperoleh reliabilitas skala resiliensi sebesar .704 dan reliabilitas alat ukur KPI sebesar .948.

\section{Analisis data}

Teknik analisis data yang digunakan dalam penelitian ini adalah analisis regresi dengan menggunakan teknik regresi linier. Hal ini dilakukan untuk menguji pengaruh resiliensi sebagai variabel independen terhadap kesejahteraan subjektif sebagai variabel dependen dalam penelitian ini. Teknik regresi linier sederhana digunakan untuk mengetahui pengaruh resiliensi terhadap kesejahteraan (well being) melalui setiap domain dalam masing-masing dimensinya dengan menggunakan bantuan program SPSS 20.

\section{Hasil}

Penelitian ini bertujuan untuk melihat apakah terdapat pengaruh antara resiliensi dengan kesejahteraan subjektif yang dimiliki andik dan melihat bagaimana pengaruhnya terhadap domain kehidupan andik selama menjalani masa binaan di LPKA. Berdasarkan hasil pengumpulan data yang didapatkan dari 83 andik LPKA Kelas II Bandung sebagai responden penelitian, maka diperoleh hasil gambaran umum yang telah dikategorikan sesuai dengan kategori dentzan (Irianto, 1998) sehingga diperoleh gambaran sebagai berikut. 
Tabel 1

Statistik Deskriptif Resiliensi

\begin{tabular}{lccccccc}
\hline Variabel & Min & Maks & $M$ & $S D$ & $n$ & $\%$ & Kategorisasi \\
\hline \multirow{3}{*}{ Resiliensi } & & & & & 26 & 31 & Sangat Tinggi \\
& \multirow{2}{*}{$* 4$} & \multirow{2}{*}{125} & \multirow{2}{*}{105.831} & 8.828 & 54 & 65 & Tinggi \\
$N$ & & & & & 3 & 4 & Rendah \\
& & & & & 0 & 0 & Sangat Rendah \\
\end{tabular}

Hasil gambaran umum resiliensi dari responden yang merupakan 83 andik Lembaga Pembinaan Khusus Anak Kelas II menunjukkan bahwa 31\% andik memiliki resiliensi dalam kelompok kategori sangat tinggi, 65\% andik memiliki resiliensi dalam kelompok kategori tinggi, dan 4\% lainnya adalah andik yang memiliki resiliensi dalam kelompok kategori rendah.

\section{Tabel 2}

Statistik Deskriptif Kesejahteraan Subjektif

\begin{tabular}{lccccccc}
\hline \multicolumn{1}{c}{ Variabel } & Min & Maks & $M$ & $S D$ & $n$ & $\%$ & Kategorisasi \\
\hline & & & & & 4 & 5 & Sangat Tinggi \\
Kesejahteraan & \multirow{2}{*}{64} & \multirow{2}{*}{144} & 117.506 & 17.3658 & 9 & 11 & Tinggi \\
Subjektif & & & & & 53 & 64 & Rendah \\
& & & & & 17 & 20 & Sangat Rendah \\
$N$ & & & & & 83 & 100 & \\
\hline
\end{tabular}

Adapun hasil gambaran umum kesejahteraan subjektif dari responden yang merupakan 83 andik Lembaga Pembinaan Khusus Anak Kelas II menunjukkan bahwa 5\% andik memiliki kesejahteraan subjektif dalam kelompok kategori sangat tinggi, 11\% andik memiliki kesejahteraan subjektif dalam kelompok kategori tinggi, $64 \%$ andik memiliki kesejahteraan subjektif dalam kelompok kategori rendah, dan 20\% lainnya adalah andik yang memiliki kesejahteraan subjektif dalam kelompok kategori sangat rendah. 
Tabel 3

Distribusi Frekuensi Kesejahteraan Subjektif pada Masing-Masing Domain

\begin{tabular}{cccccccccc}
\hline \multirow{2}{*}{ Domain } & \multicolumn{1}{c}{ Kepuasan Hidup } & \multicolumn{2}{c}{ Sikap Positif } & \multicolumn{2}{c}{ Emosi } & \multicolumn{2}{c}{ Harga Diri } & \multirow{2}{*}{ Kategorisasi } \\
\cline { 2 - 8 } Akademik & $n$ & $\%$ & $n$ & $\%$ & $n$ & $\%$ & $n$ & $\%$ & \\
\cline { 2 - 8 } & 37 & 45 & 45 & 54.2 & 41 & 49 & 50 & 60 & Sangat Tinggi \\
& 19 & 23 & 26 & 31.4 & 18 & 22 & 20 & 24 & Tinggi \\
& 21 & 25 & 6 & 7.2 & 18 & 22 & 10 & 12 & Rendah \\
Organisasi & 6 & 7 & 6 & 7.2 & 6 & 7 & 3 & 4 & Sangat Rendah \\
& 42 & 50.6 & 27 & 33 & 46 & 55.5 & 31 & 37.5 & Sangat Tinggi \\
& 30 & 36.2 & 33 & 40 & 19 & 23 & 26 & 31.5 & Tinggi \\
& 8 & 9.6 & 17 & 20 & 12 & 14.5 & 21 & 25 & Rendah \\
Interaksi & 3 & 3.6 & 6 & 7 & 6 & 7 & 5 & 6 & Sangat Rendah \\
Sosial & 38 & 45.8 & 56 & 67 & 49 & 59 & 53 & 64 & Sangat Tinggi \\
& 28 & 33.8 & 19 & 23 & 26 & 31.4 & 21 & 25 & Tinggi \\
& 14 & 16.8 & 4 & 5 & 6 & 7 & 6 & 7 & Rendah \\
Kegiatan & 3 & 3.6 & 4 & 5 & 2 & 2.6 & 3 & 4 & Sangat Rendah \\
& 39 & 47 & 48 & 58 & 52 & 62.6 & 23 & 28 & Sangat Tinggi \\
& 31 & 37.4 & 21 & 25 & 19 & 23 & 28 & 34 & Tinggi \\
& 8 & 9.6 & 10 & 12 & 11 & 13.2 & 16 & 19 & Rendah \\
& 5 & 6 & 4 & 5 & 1 & 1.2 & 16 & 19 & Sangat Rendah \\
\hline
\end{tabular}

Gambaran umum terhadap variabel kesejahteraan subjektif dari 83 andik Lembaga Pembinaan Khusus Anak Kelas II diperoleh hasil yang dilihat melalui kelompok kategori dentzan pada masing-masing dimensi dan domainnya. Berdasarkan Tabel 3 diketahui bahwa sebanyak 45\% andik memiliki kepuasan hidup yang tergolong sangat tinggi dalam domain akademik, 50.6\% dalam domain organisasi, $45.8 \%$ dalam domain interaksi sosial, dan $47 \%$ menunjukkan kepuasan hidup dalam domain kegiatan. Kemudian diketahui juga sebanyak $54.2 \%$ andik memiliki sikap positif yang tergolong sangat tinggi dalam domain akademik, 33\% dalam domain organisasi, 67\% dalam domain interaksi sosial, dan $58 \%$ menunjukkan sikap positifnya dalam domain kegiatan. Selain itu diperoleh juga data yang menunjukkan bahwa sebanyak 49\% andik memiliki emosi positif dalam domain akademik yang tergolong sangat tinggi, 55.5\% dalam domain organisasi, 59\% dalam domain interaksi sosial, 62.6\% dalam domain kegiatan. Sementara untuk dimensi harga diri menunjukkan data sebanyak $60 \%$ andik memiliki keberhargaan diri yang tergolong sangat tinggi dalam domain akademik, $37.5 \%$ dalam domain organisasi, $64 \%$ dalam domain interaksi sosial, dan 28\% lainnya menunjukkan keberhargaan diri dalam domain kegiatan. 


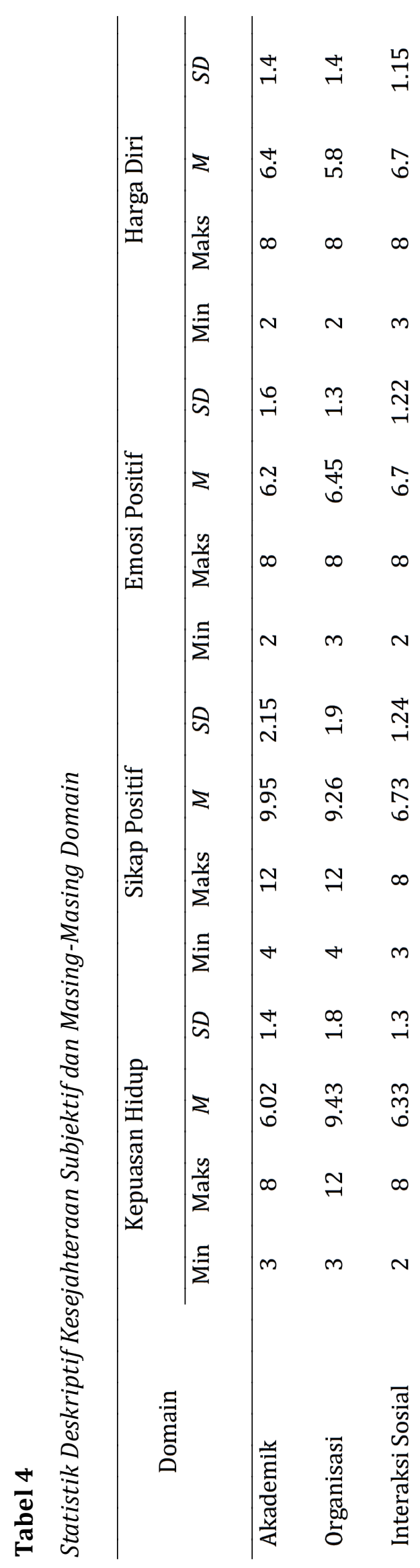




\section{Tabel 5}

Model Regresi Resiliensi - Kesejahteraan Subjektif

\begin{tabular}{|c|c|c|c|c|}
\hline Variabel & $b$ & $\beta$ & $\mathrm{t}$ & $p$ \\
\hline Resiliensi & 1.793 & .505 & 5.268 & .000 \\
\hline
\end{tabular}

Tabel 6

Koefisien Determinasi Resiliensi

\begin{tabular}{ccc}
\hline Variabel & $\mathrm{R}$ & $\mathrm{R}^{2}$ \\
\hline Resiliensi * Kesejahteraan Subjektif & $.505^{\mathrm{a}}$ & .255 \\
\hline
\end{tabular}

Catatan. a. Prediktor: (Constant), Resiliensi

Berdasarkan hasil analisis dan signifikansinya. Apabila nilai signifikansi $p$ perhitungan yang disajikan dalam Tabel $6<.05$, maka hal tersebut menunjukkan diketahui bahwa variabel resiliensi dengan bahwa kedua variabel saling memengaruhi. variabel kesejahteraan subjektif memiliki Data yang disajikan dalam tabel skor korelasi sebesar .505. Hasil tersebut menunjukkan adanya kekuatan hubungan antar variabel, yakni variabel resiliensi dengan variabel kesejahteraan subjektif. Selain itu, data dalam kedua tabel juga menunjukkan signifikansi keterkaitan antar variabel dengan melihat nilai menunjukkan signifikansi $.000<.05$ sehingga dapat dikatakan bahwa resiliensi dapat memengaruhi kesejahteraan subjektif yang dimiliki oleh andik secara signifikan. Adapun data persentase kontribusi pengaruh resiliensi terhadap kesejahteraan subjektif sebagaimana dicantumkan pada Tabel 7.

\section{Tabel 7}

Pengaruh Resiliensi terhadap Kesejahteraan Subjektif

\begin{tabular}{cccccc}
\hline Variabel & $\beta$ & $S E$ & $t$ & $p$ & $\mathrm{R}^{2}$ \\
\hline Resiliensi * Kesejahteraan Subjektif & .505 & .505 & 2.536 & .013 & $25.5 \%$
\end{tabular}




\section{Tabel 8}

Pengaruh Resiliensi terhadap Kesejahteraan Subjektif Berdasarkan Domain

\begin{tabular}{|c|c|c|c|c|c|}
\hline Domain & $\beta$ & $S E$ & $t$ & $p$ & $\mathrm{R}^{2}$ \\
\hline \multicolumn{6}{|c|}{ Kepuasan Hidup } \\
\hline \multirow{2}{*}{ Akademik } & \multirow{2}{*}{.330} & \multirow{2}{*}{.330} & 2.038 & .045 & \multirow{2}{*}{$10.89 \%$} \\
\hline & & & 3.147 & .002 & \\
\hline \multirow{2}{*}{ Organisasi } & \multirow{2}{*}{.330} & \multirow{2}{*}{.330} & 2.038 & .045 & \multirow{2}{*}{$10.89 \%$} \\
\hline & & & 3.147 & .002 & \\
\hline \multirow{2}{*}{ Interaksi Sosial } & \multirow{2}{*}{.456} & \multirow{2}{*}{.456} & 1.663 & .100 & \multirow{2}{*}{$20.8 \%$} \\
\hline & & & 4.605 & .000 & \\
\hline \multirow{2}{*}{ Kegiatan } & \multirow{2}{*}{.415} & \multirow{2}{*}{.415} & 2.604 & .01 & \multirow{2}{*}{$17.22 \%$} \\
\hline & & & 4.100 & .000 & \\
\hline \multicolumn{6}{|c|}{ Sikap Positif } \\
\hline \multirow{2}{*}{ Akademik } & \multirow{2}{*}{.359} & \multirow{2}{*}{.359} & 4.174 & .000 & \multirow{2}{*}{$12.88 \%$} \\
\hline & & & 3.457 & .001 & \\
\hline \multirow{2}{*}{ Organisasi } & \multirow{2}{*}{.441} & \multirow{2}{*}{.441} & 1.908 & .060 & \multirow{2}{*}{$19.44 \%$} \\
\hline & & & 4.426 & .000 & \\
\hline \multirow{2}{*}{ Interaksi Sosial } & \multirow{2}{*}{.404} & 404 & 5.210 & .000 & $16220 \%$ \\
\hline & & .707 & 3.978 & .000 & \\
\hline Vorinton & 250 & 250 & 5.010 & .000 & 12010 \\
\hline Negiatan & .530 & . 530 & 3.454 & .001 & $12.01 \%$ \\
\hline & & & & & \\
\hline Akademik & 498 & 498 & .975 & .333 & $2480 \%$ \\
\hline & & & 5.167 & .000 & \\
\hline Organisasi & 213 & 213 & 4.343 & .000 & $453 \%$ \\
\hline & & & 1.959 & .054 & \\
\hline Interakci Social & 381 & 381 & 5.023 & .000 & $14.50 \%$ \\
\hline 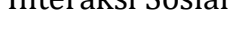 & .501 & .501 & 3.706 & .000 & $14.5 \%$ \\
\hline Keqiatan & 328 & 328 & 4.257 & .000 & 11420 \\
\hline Kegiatan & .338 & .338 & 3.231 & .002 & $11.4 \angle \%$ \\
\hline & & & & & \\
\hline Akademik & 486 & 486 & 3.378 & .001 & 226106 \\
\hline & & & 5.004 & .000 & $20.01 \%$ \\
\hline Organicaci & 210 & 210 & 1.984 & .051 & $4410 \%$ \\
\hline Organisasi & .210 & .210 & 1.930 & .057 & $4.41 \%$ \\
\hline Intoroloci Cociol & 200 & 200 & 5.843 & .000 & 0.5100 \\
\hline Interaksı sosial & .309 & .309 & 2.923 & .004 & $9.54 \%$ \\
\hline Kegiatan & 408 & 408 & 4.859 & .000 & $1664 \%$ \\
\hline & & & 4.027 & .000 & \\
\hline
\end{tabular}


Berdasarkan Tabel 7 dapat diketahui hasil perolehan skor korelasi antara variabel resiliensi dengan kesejahteraan subjektif melalui domain dalam setiap dimensinya. Perolehan skor (r) ini menunjukkan kekuatan hubungan antar variabel. Data dalam Tabel 8 juga menunjukkan signifikansi keterkaitan antarvariabel dengan melihat nilai signifikansinya. Apabila nilai signifikansi $p<.05$, maka hal tersebut menunjukkan bahwa kedua variabel saling memengaruhi. Melalui data dalam Tabel 7 diketahui ada dua dimensi dalam domain organisasi yang menunjukkan signifikansi lebih besar .05. Dengan demikian dapat dikatakan bahwa resiliensi tidak dapat memengaruhi kesejahteraan subjektif andik dalam domain organisasi pada dimensi emosi positif dan harga diri.

\section{Pembahasan}

Secara umum hasil dari penelitian sudah mampu menjawab pertanyaan dari rumusan masalah, bahwa resiliensi memiliki pengaruh yang signifikan terhadap kesejahteraan subjektif. Namun untuk melihat pengaruh tersebut dapat dikaji melalui signifikansi beserta kontribusi pengaruh variabel bebas terhadap variabel terikat. Berdasarkan uji regresi linier sederhana yang dilakukan dalam penelitian ini dapat diketahui bahwa resiliensi dapat memberikan pengaruh terhadap kesejahteraan subjektif dengan prosentase sebesar 25.5\%. Besarnya angka prosentase ini menunjukkan besarnya kontribusi pengaruh resiliensi terhadap kesejahteraan subjektif yang dimiliki andik.
Hasil dari perolehan data ini didukung dengan hasil penelitian yang dilakukan oleh Zubair et al. (2018) yang mengemukakan bahwa salah satu faktor yang dapat memprediksi kesejahteraan subjektif yang dimiliki individu adalah resiliensi karena individu dengan tingkat resiliensi tinggi adalah responden yang memiliki kemampuan untuk memberikan respon secara sehat dan mampu tetap produktif, meskipun harus menghadapi situasi yang tidak menyenangkan (Reivich \& Shatte, 2002). Individu yang memiliki kemampuan tersebut cenderung memiliki pemaknaan yang positif terhadap situasi yang dihadapinya sehingga hal tersebut dapat meningkatkan penilaian terhadap hidupnya. Pemaknaan dan penilaian tersebut merupakan bentuk dari evaluasi individu yang disebut sebagai kesejahteraan subjektif (Diener, 1984, 2000, 2009).

Hasil dari penelitian ini menunjukkan bahwa kesejahteraan subjektif andik terbukti secara signifikan dipengaruhi oleh resiliensi yang responden miliki, namun resiliensi yang dimiliki oleh andik hanya dapat memprediksi dan tidak dapat menjamin tingkat kesejahteraan subjektif yang responden miliki. Tinggi rendahnya kesejahteraan subjektif ini dapat dipengaruhi oleh berbagai faktor lain yang menunjang tingkat kesejahteraan subjektif andik, baik faktor eksternal maupun faktor internal (Khairat \& Adiyanti, 2015; Maslihah, 2017; Nadiva, 2013). 
Untuk mengetahui secara lebih jelas bagaimana resiliensi dapat memengaruhi kesejahteraan subjektif andik, berikut penjelasan terkait pengaruh resiliensi terhadap kesejahteraan subjektif yang dilihat melalui domain-domain dalam dimensi yang ada pada kesejahteraan subjektif andik LPKA Kelas II Bandung.

\section{Pengaruh resiliensi terhadap kesejahteraan subjektif pada dimensi emosi positif dan harga diri dalam domain akademik}

Melalui data hasil penelitian dapat diketahui bahwa pengaruh terbesar resiliensi terhadap kesejahteraan subjektif muncul pada domain akademik dalam dimensi emosi positif dan harga diri. Diketahui bahwa resiliensi memengaruhi subjective well being andik pada domain akademik dalam dimensi emosi positif dengan persentase sebesar $24,80 \%$, sementara dalam dimensi harga diri prosentasenya sebesar 23.61\%.. Hasil kedua pengaruh yang tinggi pada domain akademik ini sesuai dengan penelitian Tampubolon (2017) yang mengemukakan bahwa pemenuhan terhadap aspek pendidikan, kemandirian, dan pembinaan kepribadian dapat menjadi tolak ukur kesejahteraan subjektif yang dimiliki andik LPKA. Karena dengan terpenuhinya hak-hak tersebut andik LPKA akan tetap memiliki hak pendidikan yang sama seperti anak lain sesuai usianya (Ariani, 2014; Jiwantari et al., 2017).

Emosi positif yang dalam penelitian ini didefinisikan sebagai perasaan positif yang dirasakan oleh andik selama menjalani masa binaan di LPKA dalam hal ini melibatkan aspek akademik yang berada dalam ruang lingkup pendidikan. Aspek ini berusaha menunjukkan bahwa dengan adanya keterlibatan andik dalam kegiatan-kegiatan akademik termasuk kegiatan pembelajaran dapat menghindari munculnya perasaan negatif yang sewaktu-waktu berpotensi muncul selama andik menjalani masa binaan di LPKA (Maslihah, 2017; RodríguezFernández et al., 2018).

Pengendalian terhadap perasaan yang mungkin dapat muncul sewaktu-waktu tersebut akan menunjukkan sejauh mana resiliensi yang dimilikinya karena individu yang resiliensi adalah responden yang mampu mengendalikan dan mengatur emosi sekalipun dalam keadaan yang menekan (Ferawati, 2020; Reivich \& Shatte, 2002). Pengendalian terhadap emosi tersebut dapat menunjukkan kekuatan personal yang dimilikinya dan hal tersebut menjadi faktor dari dalam diri yang dapat menunjang kesejahteraan subjektif yang dimilikinya (Khairat \& Adiyanti, 2015; Nadiva, 2013; Pasudewi, 2013; Yildirim \& Belen, 2019).

Selain itu, akademik juga menjadi pengaruh terbesar kedua resiliensi terhadap kesejahteraan subjektif andik dalam dimensi harga diri dengan prosentase pengaruh sebesar 23.61\%. Hasil tersebut diperkuat dengan penelitian-penelitian sebelumnya yang mengemukakan bahwa andik yang terlibat dalam kegiatan akademik akan cenderung memiliki keberhargaan diri yang lebih tinggi. Hal ini kemudian menjadi faktor internal yang 
dapat membantu meningkatkan kesejahteraan subjektif yang dimilikinya (Kelifa et al, 2020; Khairat \& Adiyanti, 2015; Nadiva, 2013; Rodríguez-Fernández et al, 2018). Keterlibatan dalam kegiatan akademik atau aktivitas belajar juga dapat memberikan penilaian terhadap kemampuan diri sendiri dalam bidang akademik (Kelifa et al., 2020; Maslihah, 2017; RodríguezFernández et al., 2018). Penilaian terhadap kemampuan diri sendiri tersebut merupakan salah satu karakteristik seseorang dengan resiliensi yang baik (Kelifa et al, 2020; Murphy et al., 2015; Reivich \& Shatte, 2002)

Sejalan dengan hal tersebut, hasil demografi dalam penelitian ini juga menunjukkan bahwa besarnya angka prosentase tingkat kesejahteraan subjektif andik di LPKA Kelas II Bandung dapat dibuktikan dengan riwayat pendidikan terakhir yang dijalani andik, baik sebelum menjalani masa binaan di LPKA maupun selama menjalani masa binaan di LPKA. Diketahui sebanyak 74 dari 83 andik di LPKA Kelas II Bandung memiliki riwayat pendidikan SMP sampai dengan SMA. Dengan demikian dapat dikatakan bahwa sebagian besar andik di LPKA Kelas II Bandung tetap mendapatkan hak wajib belajar 12 tahun meskipun responden harus menjalani masa binaan di LPKA. Hal tersebut juga memperkuat bukti bahwa resiliensi tinggi yang dimiliki andik berpengaruh terhadap kesejahteraan subjektif yang dimilikinya, baik pada dimensi emosi positif maupun harga diri yang keduanya sama-sama berada dalam domain akademik.

\section{Pengaruh resiliensi terhadap kesejahteraan subjektif pada dimensi kepuasan hidup dalam domain interaksi sosial dan dimensi sikap positif dalam domain organisasi}

Kemudian pengaruh resiliensi terhadap kesejahteraan subjektif pada dimensi kepuasan hidup dalam domain interaksi sosial memiliki persentase sebesar $20.8 \%$ dan pengaruh resiliensi terhadap kesejahteraan subjektif pada dimensi sikap positif dalam domain organisasi dengan prosentase pengaruh sebesar $19.44 \%$. Kedua angka persentase ini dapat ditunjukkan melalui kehidupan sehari-hari andik selama menjalani masa binaan di LPKA. Andik LPKA Kelas II Bandung yang selama menjalani masa binannya hidup berkelompok bersama andik lainnya tentu perlu memiliki pola interaksi dalam kelompokyang menuntut adanya kerja sama dan munculnya pola kepemimpinan dalam diri andik. Kerja sama dan pola kepemimpinan tersebut akan muncul ketika seseorang memiliki kepercayaan pada kemampuannya sendiri untuk bisa memberikan penilaian serta mengambil keputusan. Hal tersebut dalam penelitian Murphey (2013) termasuk dalam salah satu karakteristik seseorang yang memiliki resiliensi.

Seseorang dengan resiliensi yang baik adalah seseorang yang dapat menunjukkan keyakinan untuk dapat memecahkan masalah dan menghadapi kesulitan serta memberikan evaluasi terhadap keyakinan yang dimilikinya (Megawati et al., 2019; Pasudewi, 2013; Reivich \& Shatte, 2002). Kemampuan-kemampuan tersebut turut menjadi salah satu faktor 
penunjang seseorang untuk meningkatkan kesejahteraan subjektif yang dimilikinya dalam domain organisasi (Maslihah, 2017)

Menurut penelitian Nadiva (2013), adanya kemampuan bersosialisasi dengan baik juga mendukung seseorang untuk memiliki kesejahteraan subjektif yang lebih baik karena responden mampu memunculkan sikap positif melalui pandangannya, baik dalam setiap pengambilan keputusan maupun pola interaksi dengan sesama anggota kelompok lainnya. Hal tersebut kemudian dapat menjadi faktor yang mendorong munculnya dukungan dari sesama anggota kelompok yang mampu membuat seseorang bertahan dalam situasi yang sulit atau yang disebut juga dengan resiliensi (Febrina \& Rinaldi, 2020; Kong et al, 2020; D. D. Murphey, 2013; Nadiva, 2013; Reivich \& Shatte, 2002). Dengan kata lain, andik dengan resiliensi yang baik adalah responden yang memiliki sikap positif yang tergolong tinggi dalam kehidupan beroganisasi atau kehidupan berkelompoknya, sehingga hal tersebut turut meningkatkan kesejahteraan subjektif yang dimilikinya.

\section{Pengaruh resiliensi terhadap kesejahteraan subjektif pada dimensi kepuasan hidup dan harga diri dalam domain kegiatan}

Selanjutnya, diketahui juga bahwa resiliensi memberikan pengaruh yang signifikan terhadap kesejahteraan subjektif andik LPKA Kelas II Bandung pada domain kegiatan. Kedua pengaruh ini masing-masing menyumbangkan prosentase kontribusi sebesar $17.22 \%$ dalam dimensi kepuasan hidup dan $16.64 \%$ pada dimensi harga diri. Hal ini mengindikasikan bahwa andik yang memiliki resiliensi yang baik adalah andik yang merasa puas dengan kehidupan yang dimilikinya dan memiliki harga diri yang tinggi karena mampu terlibat dalam kegiatan-kegiatan yang dilakukan di LPKA. Temuan ini didukung dengan hasil dari penelitian Maslihah etal. (Maslihah etal., 2017) yang mengemukakan bahwa kegiatan yang meliputi keterlibatan andik dalam kegiatan selama menjalani masa binaan di LPKA turut berkontribusi dalam proses perkembangan diri andik. Hal ini dapat memberikan dampak positif terhadap munculnya potensi-potensi baru dan perubahan ke arah yang lebih positif dalam diri andik. Adanya potensi dan perubahan tersebut merupakan suatu bentuk kepuasan hidup (Maslihah, 2017; Satici, 2016; Zubair et al, 2018).

Selain merasakan kepuasan, dengan adanya keterlibatan andik dalam kegiatankegiatan pengembangan diri meskipun responden sedang menjalani masa binaan di LPKA, andik LPKA Kelas II Bandung juga tetap menunjukkan bahwa responden cenderung memiliki harga diri yang tinggi. Hal ini didukung oleh hasil dari penelitian Murphey (2013) yang mengemukakan bahwa keterlibatan individu dalam kegiatan pengembangan diri juga dapat membantu responden mengembangkan kemampuan dan kepercayaan dirinya.

Selain itu, keterlibatan andik dalam kegiatan juga dapat memberikan dampak positif terhadap penilaian ndik terhadap dirinya 
sendiri yang dapat meliputi penilaian terhadap optimisme, kemampuan menyesuaikan diri, kemampuan mengatasi masalah, dan harapan tentang masa depan yang berdampak kepada keberhargaan diri yang dimiliki oleh andik (Khairat \& Adiyanti, 2015; Nadiva, 2013; Satici, 2016). Harga diri yang dalam hal ini dimiliki oleh andik berkaitan dengan kompetennsi serta kemampuan dalam aspek kognitif, dan emosi.

Kemampuan-kemampuan tersebut tentu tidak akan muncul tanpa adanya pengakuan dan adanya perasaan dibutuhkan, sehingga dalam hal ini pengakuan diperlukan agar andik LPKA mampu memotivasi dirinya untuk tetap terlibat dalam kegiatan-kegiatan pembinaan di LPKA (Ayu et al., 2017; Maslihah, 2018; Maslihah et al., 2017). Beberapa contoh kegiatan pembinaan yang membantu proses pengembangan diri andik selama menjalani masa binaan di LPKA Kelas II Bandung di antaranya adalah futsal, pramuka, pesantren, sosialisasi dan penyuluhan, serta programprogram latihan kerja yang biasa diselenggarakan oleh Lembaga Advokasi dan Hak Anak (LAHA) (Septiani, 2019).

\section{Pengaruh resiliensi terhadap kesejahteraan subjektif pada dimensi sikap positif dan emosi positif dalam domain interaksi sosial}

Selanjutnya resiliensi juga diketahui memberikan pengaruh yang cukup besar terhadap kesejahteraan subjektif dalam domain interaksi sosial. Pengaruh tersebut dapat terlihat pada dimensi sikap positif dan emosi positif dengan masing-masing kontribusi pengaruh sebesar $16.32 \%$ dan $14.5 \%$. Hal ini dapat terlihat melalui pola hubungan interpersonal andik selama menjalani masa binaan di LPKA karena pada domain interaksi ini ditunjukkan bagaimana relasi interpersonal andik baik dengan sesama andik lainnya maupun dengan petugas LPKA. Temuan ini didukung oleh penelitian Murphey (2013) yang mengemukakan bahwa individu yang cenderung easygoing dengan pembawaan yang mudah untuk bersosialisasi adalah salah satu karakteristik seseorang yang memiliki resiliensi.

Hubungan interpersonal dan bagaimana pembawaan seseorang dalam kehidupan sosialnya dapat memengaruhi kesejahteraan subjektif yang dimilikinya karena hal tersebut dapat menjadi faktor pendorong dari luar diri individu untuk mendapatkan dukungan serta merasakan kepuasan dalam hidupnya (Febrina \& Rinaldi, 2020; Kansky \& Diener, 2017; Khairat \& Adiyanti, 2015; Kong et al., 2020; Maslihah, 2018; Sari \& Maryatmi, 2019). Andik yang memiliki keterampilan sosial atau interaksi sosial yang baik juga cenderung memiliki resiliensi yang baik sehingga tingkat kesejahteraan subjektif yang dimilikinya pun akan meningkat (Kansky \& Diener, 2017). Dukungan tersebut yang kemudian dapat memengaruhi tinggi rendahnya kesejahteraan subjektif yang dimiliki oleh andik yang menjalani masa binaan di LPKA Kelas II Bandung (Febrina \& Rinaldi, 2020; Kansky \& Diener, 2017; Khairat \& Adiyanti, 2015; Kong 
et al., 2020; Maslihah, 2018; Maslihah et al., 2017; Nadiva, 2013; Sari \& Maryatmi, 2019).

Adanya dukungan dari luar diri andik dapat membuat andik mampu memandang hal tersebut sebagai suatu hal yang positif dan menjadikan hal tersebut sebagai salah satu sumber kekuatan personal miliknya yang berasal dari luar (Febrina \& Rinaldi, 2020; Kong et al,, 2020; Markson et al, 2016; Maslihah, 2018; Sari \& Maryatmi, 2019).Pandangan positif tersebut yang dalam penelitian Maslihah et al. (Maslihah et al., 2017) disebut sebagai sikap positif yang dapat menjadi salah satu tolak ukur kesejahteraan subjektif yang dimiliki andik.

Selain memunculkan pandangan positif, interaksi sosial yang dimiliki andik juga dapat memunculkan perasaan positif yang bersumber dari adanya rasa kebersamaan yang dirasakan selama menjalani masa binaan di LPKA (Septiani, 2019). Hal ini didukung dengan pernyataan dalam beberapa penelitian sebelumnya yang mengemukakan bahwa individu dengan resiliensi yang baik adalah individu yang tidak sendiri, responden akan cenderung memiliki orang-orang di sekitar responden yang mampu memberikan dukungan sehingga responden mampu menjadikan dukungan tersebut sebagai salah satu sumber kekuatan dari apa yang responden miliki (Kong et al., 2020; Markson et al., 2016; Maslihah, 2018; D. D. Murphey, 2013; Pasudewi, 2013; Sari \& Maryatmi, 2019). Perasaan tersebut dalam konsep kesejahteraan (well being) Maslihah et al.
(2017) disebut sebagai emosi positif yang juga menjadi salah satu tolak ukur kesejahteraan subjektif yang dimiliki oleh andik di LPKA Kelas II Bandung.

\section{Pengaruh resiliensi terhadap kesejahteraan subjektif pada dimensi sikap positif dalam domain akademik dan domain kegiatan}

Kemudian, diketahui pula bahwa resiliensi andik LPKA Kelas II Bandung juga secara signifikan memengaruhi kesejahteraan subjektif pada dimensi sikap positif, baik dalam domain akademiknya maupun dalam domain kegiatan yang diikutinya. Kedua pengaruh tersebut masing-masing menunjukkan prosentase kontribusi sebesar $12.88 \%$ dan $12.81 \%$. Pengaruh tersebut ditunjukkan melalui munculnya pandangan yang positif terhadap suatu peristiwa atau pun kondisi yang dihadapi andik selama menjalani masa binaan di LPKA. Hal tersebut sesuai dengan pernyataan dalam penelitian Reivich dan Shatte (2002) yang mengemukakan bahwa pandangan positif yang dimiliki seseorang sehingga seseorang tersebut mampu berpikir bahwa apa yang dihadapinya bukanlah suatu titik akhir dapat muncul ketika seseorang tersebut memiliki resiliensi yang baik.

Optimisme yang dimiliki oleh andik yang meyakini bahwa kesulitan yang dihadapinya bukan merupakan suatu titik akhir dan adanya keyakinan bahwa hari esok akan lebih baik juga turut mendorong andik untuk memiliki motivasi dalam mengembangkan dirinya, baik melalui domain akademik maupun domain 
kegiatan (Pasudewi, 2013; Reivich \& Shatte, 2002; Satici, 2016; Yildirim \& Belen, 2019; Zubair et al., 2018). Motivasi tersebut dapat mendorong andik untuk tetap mengikuti aktivitas belajar meskipun di tengah-tengah masa binaan yang dijalaninya. Hal ini dibuktikan dengan jumlah sebagian besar andik di LPKA Kelas II Bandung yang tetap melanjutkan pendidikannya selama menjalani masa binaan di LPKA. Sebanyak 74 dari 83 andik di LPKA Kelas II Bandung memiliki riwayat pendidikan minimal sampai dengan sekolah menengah pertama (SMP).

\section{Pengaruh resiliensi terhadap kesejahteraan subjektif pada dimensi emosi dalam domain kegiatan}

Selain memengaruhi domain akademik, resiliensi juga memengaruhi sikap positif dalam subjective well being andik LPKA Kelas II Bandung melalui domain kegiatan. Sejalan dengan pengaruh terhadap domain akademik, pengaruh terhadap domain kegiatan ini dapat ditunjukkan melalui keterlibatan andik pada setiap kegiatan-kegiatan pembinaan yang responden ikuti selama menjalani masa binaan di LPKA. Hal ini sesuai dengan hasil dalam penelitian Maslihah et al. (2015) yang menyebutkan bahwa dengan ikut terlibat pada kegiatan pengembangan diri selama menjalan masa binaan di LPKA dapat membantu andik mengalihkan pikiran-pikiran negatif yang berpotensi muncul selama menjalani masa binaan di LPKA. Teralihkannya pikiran-pikiran negatif tersebut akan mendorong andik untuk tidak menyikapi keadaan yang dihadapinya sebagai sesuatu hal yang negatif (Bajaj \& Pande, 2016; Chen et al., 2017; Ferawati, 2020). Temuan tersebut juga didukung oleh hasil penelitian Teall et al. (2013) yang mengemukakan bahwa pandangan yang dimiliki seseorang terhadap suatu peristiwa dalam hidupnya dapat muncul ketika seseorang mampu mengatasi dan memperbaiki keadaan menjadi lebih baik atau yang dalam hal ini disebut juga sebagai resiliensi.

Dengan demikian dapat disimpulkan bahwa resiliensi dapat memunculkan pandangan positif yang membuat andik mampu menyikapi suatu hal sebagai sesuatu yang positif dan bersedia mengikuti kegiatan yang dapat membantu mengembangkan potensi dirinya (Maslihah, 2017; Murphey, 2013; Reivich \& Shatte, 2002; Satici, 2016; Zubair et al., 2018). Keterlibatan dengan kegiatan pengembangan diri tersebut juga dapat membantu andik untuk mengalihkan pikiranpikiran negatif yang mungkin sewaktu-waktu dapat muncul, sehingga hal tersebut berpengaruh terhadap kesejahteraan subjektif yang dimilikinya (Ayu et al., 2017; Maslihah et al., 2015; Satici, 2016). Oleh karena itu sebagai salah satu upaya untuk membuat andik memiliki pandangan dan mampu menunjukkan sikap positif yang dapat membantu mengalihkan dari pikiran negatif serta emosi negatif maka andik perlu dilibatkan dalam kegiatan-kegiatan yang dapat membantu mengembangkan dirinya (Ayu et al., 2017; 
Tampubolon, 2017). Hal ini dapat dilakukan melalui aktivitas belajar atau yang berkaitan dengan akademik maupun dengan kegiatankegiatan pengembangan diri lainnya. Karena di sisi lain, resiliensi juga memberikan pengaruh yang cukup signifikan terhadap kesejahteraan subjektif pada dimensi emosi positif melalui domain yang sama, yakni domain kegiatan, dengan kontribusi pengaruh sebesar $11.42 \%$.

\section{Pengaruh resiliensi terhadap kesejahteraan subjektif pada dimensi kepuasan hidup dalam domain akademik dan organisasi}

Selanjutnya resiliensi juga memberikan pengaruh dengan prosentase yang sama besar terhadap kesejahteraan subjektif pada dimensi kepuasan hidup dalam domain akademik dan organisasi, yakni sebesar $10.89 \%$. Nilai prosentase pengaruh yang sama besar ini menunjukkan bahwa resiliensi berpengaruh sama besar terhadap kepuasan hidup andik LPKA Kelas II Bandung melalui domain akademik dan domain organisasi yang kedua hal tersebut turut berkontribusi dalam tingkat kesejahteraan subjektif yang responden miliki. Temuan ini sesuai dengan penelitian Reivich dan Shatte (2002) yang mengemukakan bahwa salah satu kunci kesuksesan dan kepuasan hidup seseorang dapat dilihat melalui resiliensi yang dimilikinya.

Hal ini juga sejalan dengan temuan dalam penelitian Maslihah et al. (2017) bahwa kepuasan hidup andik dapat berupa penilaian kognitif terkait perubahan-perubahan positif yang dalam hal ini dapat dilihat melalui aktivitas belajar atau kegiatan pendidikan lainnya serta motivasi terkait potensi-potensi akademik yang dimilikinya. Besarnya jumlah andik LPKA Kelas II Bandung yang tetap memperoleh pendidikan layak sampai dengan SMP paralel dengan hasil dari kepuasan hidup yang menunjukkan tingginya kesejahteraan subjektif yang responden miliki.

Selain di ranah akademik, kepuasan hidup dalam hal ini juga dapat ditunjukkan juga melalui ranah kehidupan berorganisasi yang menggambarkan pola kepemimpinan, kerjasama, pengambilan keputusan, dan kehidupan berkelompok selama menjalani masa binaan di LPKA. Transisi kehidupan yang dialami andik LPKA dari kehidupan sehari-hari pada umumnya menjadi hidup berkelompok bersama andik lainnya dalam asrama tentu akan memunculkan pola adaptasi baru yang perlu responden miliki (Ayu et al., 2017; Febrina \& Rinaldi, 2020; Riza \& Herdiana, 2012).

Perubahan-perubahan yang dialami oleh andik tersebut akan dapat memunculkan potensi-potensi baru dalam diri responden. Hal tersebut dalam konsep kesejahteraan (well being) Maslihah et al. (2017) disebut sebagai kepuasan hidup yang menjadi salah satu tolak ukur kesejahteraan subjektif bagi andik LPKA. Secara garis besar dapat dikatakan bahwa andik LPKA yang memiliki resiliensi yang baik akan mampu menunjukkan pola adaptasi yang membawa responden pada perubahan yang memunculkan potensi-potensi baru serta tetap memiliki optimisme untuk mengikuti kegiatan akademik. Hal tersebut yang 
kemudian menjadi salah satu bentuk kepuasan hidup yang dapat meningkatkan kesejahteraan subjektif yang responden miliki (Satici, 2016).

\section{Pengaruh resiliensi terhadap kesejahteraan subjektif pada dimensi harga diri dalam domain interaksi sosial}

Selanjutnya resiliensi juga diketahui memengaruhi kesejahteraan subjektif pada dimensi harga diri melalui domain interaksi sosial dengan prosentase pengaruh sebesar 9.54\%. Salah satu hal yang dapat memengaruhi adanya resiliensi adalah hubungan terpercaya yang didapatkan melalui kemampuan sosialisasi seorang individu (Kansky \& Diener, 2017; Pasudewi, 2013). Kemampuan yang menunjang adanya resiliensi tersebut kemudian menjadi salah satu kompetensi sosial andik yang dalam konsep kesejahteraan (well being) Maslihah etal. (2017) merupakan bagian dari harga diri yang dapat menjadi salah satu tolak ukur tingkat kesejahteraan subjektif yang dimiliki oleh andik. andik dengan resiliensi yang baik adalah responden yang memiliki hubungan terpercaya dalam kehidupan sosialnya sehingga hal tersebut dapat menunjukkan harga diri responden karena hal tersebut merupakan bagian dari pola interaksi sosial yang dimilikinya (Kansky \& Diener, 2017; Maslihah et al., 2017; Pasudewi, 2013). Hal tersebut kemudian dapat menunjukkan tingkat kesejahteraan subjektif yang dimiliki oleh andik.

Resiliensi tidak berpengaruh terhadap kesejahteraan subjektif pada dimensi

\section{emosi positif dan harga diri dalam domain organisasi}

Selain menunjukkan pengaruh yang signifikan, dalam penelitian ini juga terdapat dua dimensi kesejahteraan subjektif dalam domain organisasi yang tidak dapat dipengaruhi oleh resiliensi. Hal ini mengindikasikan bahwa resiliensi tidak memiliki peran untuk memengaruhi domain organisasi dalam kesejahteraan subjektif pada dimensi emosi positif dan dimensi harga diri. Berdasarkan indikasi tersebut, muncul asumsi bahwa emosi positif yang dimiliki oleh andik tidak dapat dilihat melalui kehidupan berorganisasi atau kehidupan berkelompok yang dijalani andik karena dalam kehidupan berkelompok tersebut andik lebih memerlukan adanya interaksi sosial untuk bisa menjalin kerja sama yang baik. Begitu pula untuk dimensi harga diri, peneliti juga berasumsi bahwa harga diri andik LPKA Kelas II Bandung tidak dapat dilihat melalui domain organisasi karena untuk menjalin kehidupan berorganisasi andik dapat saling menunjukkan dirinya, baik sebagai pemimpin dalam kelompok, maupun sebagai pengikut. Untuk memiliki penghargaan diri melalui hal tersebut diperlukan kemampuan sosial yang dimiliki oleh masing-masing andik.

Berdasarkan pembahasan terhadap keseluruhan hasil penelitian, dapat diketahui bahwa untuk dapat mencapai kesejahteraan subjektif yang tinggi maka andik perlu meningkatkan resiliensi yang dimilikinya. Karena dalam penelitian ini resiliensi memiliki 
peran sebagai prediktor kesejahteraan subjektif yang dimiliki oleh andik, dalam penerapannya hal ini perlu dilihat melalui masing-masing domain atau area kehidupan yang dijalani andik selama melalui masa pembinaan di LPKA. Melalui hasil analisis dalam penelitian ini diketahui bahwa besarnya pengaruh resiliensi pada kesejahteraan subjektif andik pada masing-masing domain dapat memberikan bukti bahwa resiliensi yang dimiliki andik dapat meningkatkan kesejahteraan subjektif responden jika dilihat melalui domain terkait. Dalam proses peningkatan kesejahteraan subjektif yang responden miliki, selain meningkatkan resiliensi andik, juga perlu dilibatkan dalam setiap domain atau area terkait.

Pada domain akademik, andik diharapkan dapat mengikuti program pendidikan yang diselenggarakan pihak LPKA agar andik senantiasa mencapai kepuasan dalam area akademiknya. Kemudian untuk domain organisasi, andik diharapkan dapat ikut serta dalam kehidupan berorganisasi yang ada di LPKA, baik melalui ekstrakurikuler yang diselenggarakan di LPKA maupun dalam kehidupan berkelompok bersama warga binaan lainnya. Selanjutnya, untuk domain interaksi sosial, Andik diharapkan mampu membangun hubungan dan pola interaksi yang baik dengan baik dengan sesama warga binaan lainnya maupun dengan petugas pembinaan di LPKA sehingga andik dapat memiliki pemaknaan yang positif terhadap kehidupan sosial selama menjalani masa binaan di LPKA. Sementara untuk domain kegiatan, andik diharapkan mampu terlibat aktif dalam kegiatan-kegiatan yang diselenggarakan di LPKA, hal ini dapat berupa keikutsertaan andik dalam kegiatan pembinaan yang secara khusus diberikan oleh pihak LPKA atau pun kegiatan lain yang diselenggarakan bagi andik LPKA, baik program pelatihan kerja maupun program asesmen dan penelitian dari instansi yang diberikan kewenangan oleh lembaga terkait.

Penelitian terkait pengaruh resiliensi terhadap kesejahteraan subjektif andik ini masih memiliki beberapa keterbatasan penelitian. Populasi dan sampel dalam penelitian ini dirasa masih belum maksimal. Hal ini dikarenakan keterbatasan situasi dan kondisi yang perlu disesuaikan dengan kegiatan pembinaan yang ada di LPKA Kelas II Bandung sehingga andik yang dapat berpartisipasi dalam penelitian ini hanya sejumlah 83 andik.

\section{Simpulan}

Penelitian ini bertujuan untuk melihat apakah terdapat pengaruh antara resiliensi dengan kesejahteraan subjektif yang dimiliki andik dan melihat bagaimana pengaruhnya terhadap domain kehidupan andik selama menjalani masa binaan di LPKA. Berdasarkan hasil penelitian terkait pengaruh resiliensi terhadap kesejahteraan subjektif andik Lembaga Pembinaan Khusus Anak (LPKA) Kelas II Bandung dapat diperoleh hasil simpulan bahwa sebagian besar andik LPKA Kelas II 
Bandung memiliki resiliensi di atas rata-rata. Kedua, kesejahteraan subjektif yang dimiliki andik LPKA Kelas II Bandung dapat terlihat melalui domain akademik, domain organisasi, domain interaksi sosial, dan domain kegiatan. Ketiga, terdapat pengaruh yang signifikan antara resiliensi dengan kesejahteraan subjektif yang dimiliki oleh andik LPKA Kelas II Bandung. Pengaruh ini juga dapat dilihat melalui domain dalam masing-masing dimensi variabel kesejahteraan subjektif.

\section{Saran}

Adapun saran bagi pihak-pihak yang terlibat dalam penelitian ini maupun bagi keperluan penelitian selanjutnya adalah bahwa:

1. Untuk mendapatkan gambaran yang lebih luas mengenai kesejahteraan subjektif atau pun resiliensi andik di LPKA, peneliti menyarankan penelitian berikutnya untuk memperbanyak sample dengan menggabungkan metode lain untuk bisa mendapatkan kesimpulan yang lebih umum terkait kesejahteraan subjektif atau pun resiliensi yang dimiliki oleh andik LPKA Kelas II Bandung.

2. Hasil penelitian ini bersifat umum dan belum dispesifikasikan berdasarkan kasus andik sehingga belum menggambarkan faktorfaktor lain yang kemungkinan dapat memengaruhi kesejahteraan subjektif ataupun resiliensi andik di LPKA. Diharapkan peneliti selanjutnya dapat melakukan penelitian lebih mendalam yang mampu menggali faktor lain yang kemungkinan berpengaruh terhadap kesejahteraan subjektif atau pun resiliensi yang dimiliki oleh andik di LPKA Kelas II Bandung.

3. Bagi pihak LPKA diharapkan untuk lebih memperhatikan kesejahteraan subjektif andik LPKA melalui program pembinaan dan pelatihan yang dapat meningkatan afeksi positif serta melatih andik untuk memiliki harapan hidup yang lebih positif. Program pembinaan dan pelatihan untuk meningkatkan kesejahteraan subjektif andik ini dapat dilakukan pada berbagai domain dalam kehidupan sehari-hari andik selama menjalani masa binaan di LPKA Kelas II Bandung. Program tersebut dapat dilakukan pada kehidupan akademik, kehidupan berorganisasi, interaksi sosial di kehidupan sehari-hari andik, dan kegiatan yang dilakukan andik selama menjalani masa binaan di LPKA Kelas II Bandung.

\section{Referensi}

Achour, M., Binti Abdul Ghani Azmi, I., Bin Isahak, M., Mohd Nor, M. R., \& Mohd Yusoff, M. Y. Z. (2019). Job stress and nurses well-being: Prayer and age as moderators. Community Mental Health Journal, 55(7), 1226-1235. https:// doi.org/10.1007/s10597-019-00410-y

Afirio, Y., \& Raharjo, W. (2016). Hubungan dukungan sosial keluarga dan tingkat depresi narapidana remaja di lembaga pembinaan khusus anak pontianak program. Jurnal Kesehatan Khatulistiwa, 2(1), 285-294. https:// jurnal.untan.ac.id/index.php/jfk/article/ view/29467 
Agustine, E., Sutini, T., \& Mardhiyah, A. (2018). Skrining perilaku remaja di Lembaga Pembinaan Khusus Anak (LPKA) kelas II Bandung. Jurnal Keperawatan Komprehensif, 4(1), 32. https://doi.org/ 10.33755/jkk.v4i1.96

Ariani, N. V. (2014). Implementasi UndangUndang Nomor 11 Tahun 2012 tentang sistem peradilan pidana anak dalam upaya melindungi kepentingan anak. Jurnal Media Hukum, 21(1), 107 - 122. https://journal.umy.ac.id/index.php/ jmh/article/view/1160

Atikasuri, Maya, Mediani, H. S., \& Fitria, N. (2018). Tingkat kecemasan pada andik Usia 14-18 tahun menjelang bebas di Lembaga Pembinaan Khusus Anak kelas II. JNC, 1(1), 78 - 84. http:// jurnal.unpad.ac.id/jnc/article/view/ 15773

Ayu, F. D., Hidayati, N. O., \& Mardhiyah, A. (2017). Gambaran resiliensi pada remaja. Jurnal Keperawatan 'Aisyiyah, 4(1), 13-21. h t t p : / / jour n a l.s t i ke s aisyiyahbandung.ac.id/index.php/jka/ article/view/2

Bajaj, B., \& Pande, N. (2016). Mediating role of resilience in the impact of mindfulness on life satisfaction and affect as indices of subjective well-being. Personality and Individual Differences, 93, 63-67. https:/ /doi.org/10.1016/j.paid.2015.09.005

Barczyk, A. N., Thompson, S. J., \& Rew, L. (2014). The impact of psychosocial factors on subjective well-being among homeless young adults. Health \& Social Work, 39(3), 172-180. https://doi.org/ 10.1093/hsw/hlu020

Bloem, O., Bulten, E., \& Verkes, R.-J. (2019). Changes in subjective well-being of prisoners on remand. International Journal of Prisoner Health, 15(2), 181191. https://doi.org/10.1108/IJPH-012018-0003

Chen, W., Zhang, D., Pan, Y., Hu, T., Liu, G., \& Luo, S. (2017). Perceived social support and self-esteem as mediators of the relationship between parental attachment and life satisfaction among Chinese adolescents. Personality and Individual Differences, 108, 98-102. h ttps://doi.org/10.1016/ j.paid.2016.12.009

Coyle, L. D., \& Vera, E. M. (2013). Uncontrollable stress, coping, and subjective well-being in urban adolescents. Journal of Youth Studies, 16(3), 391-403. https://doi.org/ 10.1080/13676261.2012.756975

de Ruigh, E. L., Popma, A., Twisk, J. W. R., Wiers, R. W., van der Baan, H. S., Vermeiren, R. R. J. M., \& Jansen, L. M. C. (2019). Predicting quality of life during and post detention in incarcerated juveniles. Quality of Life Research, 28(7), 1813-1823. https:// doi.org/10.1007/s11136-019-02160-6

Diener, E. (1984). Subjective well-being. In Psychological Bulletin (Vol. 95, Issue 3, pp. 542-575). American Psychological Association. https://doi.org/10.1037/ 0033-2909.95.3.542

Diener, E. (2000). Subjective well-being the science of happiness and a proposal for a national index. American Psychologist, 55(1), 34-43. https://doi.org/10.1037/ 0003-066X.55.1.34

Diener, E. (2009). Assessing well-being: The collected works of Ed Diener. In Social Indicator Research Series (Vol. 39). https://doi.org/10.1007/978-90-4812354-4_3.

Diener, E., \& Ryan, K. (2009). Subjective well being: A general review. Psychological Society of South Africa, 39(4), 391 - 406. h ttps://doi.org/10.117 / 008124630903900402

Febrina, H., \& Rinaldi. (2020). Hubungan dukungan sosial teman sesama warga binaan dengan kesejahteraan subjektif warga binaan lapas kelas IIA Padang. Jurnal Riset Psikologi, 2020(2), 1-12. https://doi.org/10.24036/ jrp.v2020i2.8605

Ferawati, A. R. (2020). Hubungan antarapemaafan diri dengan regulasi 
emosi pada anak didik Lembaga Pembinaan Khusus Anak (LPKA) kelas I Kutoarjo dan kelas II Yogyakarta. Jurnal Empati, 8(3), 82 - 88. https:// ejournal3.undip.ac.id/index.php/ empati/article/view/26498

Göcen, G. (2019). Forgiveness, gratitude and subjective well-being in boys juvenile delinquent (p. 2). https:// www.academia.edu/36765793/ Forgiveness_Gratitude_and_ Subjective_Well_ Being_i n Boys_Juvenile_Delinquent

Irianto, A. (1998). Statistika pendidikan I. Departemen Pendidikan dan Kebudayaan Dirjen Dikti-P2LPTK.

Jiwantari, A. R., Mukhneri, \& Zulaikha, S. (2017). Manajemen pembinaan anak didik pemasyarakatan studi kasus LPKA Kelas II Jakarta. Improvement: Jurnal Ilmiah Untuk Peningkatan Mutu Manajemen Pendidikan, 4(1), 93 - 103. https:// doi.org/10.21009/improvement04111

Kansky, J., \& Diener, E. (2017). Benefits of wellbeing: Health, social relationships, work, and resilience. Journal of Positive Psychology and Well Being, 1(2), 129169. https://journalppw.com/index.php/ JPPW/article/view/20

Kelifa, M. O., Yang, Y., Carly, H., Bo, W., \& Wang, P. (2020). How adverse childhood experiences relate to subjective wellbeing in college students: The role of resilience and depression. Journal of Happiness Studies. https://doi.org/ 10.1007/s10902-020-00308-7

Kemenkumham. (2019). Data terakhir jumlah penghuni perkanwil. Sistem Database Permasyarakatan. http:// smslap.ditjenpas.go.id/public/grl/ current

Khairat, M., \& Adiyanti, M. (2015). Self-esteem dan prestasi akademik sebagai prediktor subjective well being remaja awal. Gadjah Mada Journal of Psychology, 1(3), 180 - 191. https://doi.org/10.22146/ gamajop.8815
Kirmani, M. N., Sharma, P., \& Sanam, R. (2015). Hope, resilience and subjective wellbeing among college going adolescent girls. International Journal of Humanities \& Social Science Studies (IJHSSS), 2(2), 262-270. http://oaji.net/articles/2015/ 1115-1438581068.pdf

Kong, F., Yang, K., Yan, W., \& Li, X. (2020). How does trait gratitude relate to subjective well-being in Chinese adolescents? The mediating role of resilience and social support. Journal of Happiness Studies, 1 - 12. https://doi.org/10.1007/s10902020-00286-w

Lyu, S.-Y., Chi, Y.-C., Farabee, D., Tsai, L.-T., Lee, M.-B., Lo, F.-E., \& Morisky, D. (2015). Psychological distress in an incarcerated juvenile population. Journal of the Formosan Medical Association = Taiwan Yi Zhi, 114(11), 1076-1081. https:// doi.org/10.1016/j.jfma.2014.03.011

Markson, L., Lamb, M. E., \& Lösel, F. (2016). The impact of contextual family risks on prisoners' children's behavioural outcomes and the potential protective role of family functioning moderators. European Journal of Developmental Psychology, 13(3), 325-340. https:// d o i . o r g / 10 . 1080 / 17405629.2015.1050374

Maslihah, S. (2017). Faktor yang memengaruhi kesejahteraan subyektif anak didik lembaga pembinaan khusus anak. Jurnal Psikologi Insight, 1(1), 82 - 94. https:// ejournal.upi.edu/index.php/insight/ article/view/8446

Maslihah, S. (2018). Strategi koping, dukungan petugas, dan kesejahteraan psikologis anak berkonflik dengan hukum. Psympathic Jurnal Ilmiah Psikologi, 5(1), 13 - 22. https://doi.org/10.15575/ psy.v5i1.2320

Maslihah, S., Siregar, J. R., Agustiani, H., \& Koesma, R. E. (2017). Deskripsi alatukur kesejahteraan psikologis integratif anak didik lembaga pembinaan khusus anak. Universitas Pendidikan Indonesia. 
Maslihah, S., Sirogar, J. R., Koesma, R. E., \& Agustiani, H. (2015). Analisis kesejahteraan subyektif anak didik lembaga pemasyarakatan anak. Proceeding Konferensi Nasional Optimalisasi Community Well-Being dalam Perspektif Multidisipliner, 1 - 8. http://repository.maranatha.edu / 20473/1/2015 konferensi nasional heliany.pdf

Megawati, P., Lestari, S., \& Lestari, R. (2019). Gratitude training to improve subjective well-being among adolescents living in orphanges. Humanitas Indonesian Psychological Journal, 16(1), 13 - 22. http:// journal.uad.ac.id/index.ph p / HUMANITAS/article/view/9196

Murphey, D. D. (2013). Social resilience in the neoliberal era. The Journal of Social, Political, and Economic Studies, 38(4), $484-490$.

Murphey, D., Megan, B. ., \& Rigitte, V. (2013). Positive mental health: Resilience. Child Trends Adolescent Health Highlight, 3, 16. $\quad$ https://doi.org/10.1037/ e538142013-001

Murphy, T. P., Laible, D. J., Augustine, M., \& Robeson, L. (2015). Attachment's links with adolescents' social emotions: The roles of negative emotionality and emotion regulation. The Journal of Genetic Psychology: Research and Theory on Human Development, 176(5), 315-329. https://doi.org/10.1080/ 00221325.2015 .1072082

Nadiva, A. (2013). Subjective well-being pada peserta akselerasi. Calyptra, 2(1), 1 - 13. https://journalubaya.ac.id/index.php/ jimus/article/view/145

Pasudewi, C. Y. (2013). Resiliensi pada remaja binaan BAPAS ditinjau dari coping stress. Universitas Negeri Semarang.

Putra, M., Hidayati, N., \& Nurhidayah, I. (2016). Hubungan motivasi berprestasi dengan adversity quotient warga binaan remaja di LPKA kelas II Sukamiskin Bandung.
Jurnal Pendidikan Keperawatan Indonesia, 2(1), 52-61. https://doi.org/ 10.17509/jpki.v2i1.2853

Reivich, K., \& Shatte, A. (2002). The resilience factors: 7 keys to finding your inner strength and overcoming life's hurdles. Three Rivers Press.

Riza, M., \& Herdiana, I. (2012). Resiliensi pada narapidana laki-laki di lapas kelas 1 Medaeng. Jurnal Psikologi Kepribadian Dan Sosial, 1(3), 142 - 147. https:// www.e-jurnal.com/2013/09/resiliensipada-narapidana-laki-laki-di.html

Rizki, R. N., Murad, A., \& Damayanti, N. (2019). Kesejahteraan subjektif pada remaja di lapas kelas IIB di Kualasimpang. Proceeding: The Dream of Millenial Generation to Grow. http:// proceeding.uma.ac.id/index.php/ ptdomgtg/article/view/155

Rodríguez-Fernández, A., Ramos-Díaz, E., \& Axpe, I. (2018). The role of resilience and psychological well-being in school engagement and perceived academic performance: An exploratory model to improve academic achievement. In Health and Academic Achievement. h ttp s: / / do i.org/10.5772/ intechopen.73580

Sari, F. I. P., \& Maryatmi, A. S. (2019). Hubungan antara konsep diri (dimensi internal) dan optimisme dengan subjective well-being siswa SMA Marsudirini Bekasi. IkraithHumaniora, 3(1), 23-29. https:// journals.upi-yai.ac.id/index.php/ikraithhumaniora/article/view/371

Satici, S. A. (2016). Psychological vulnerability, resilience, and subjective well-being: The mediating role of hope. Personality and Individual Differences, 102, 68-73. h ttp s : / / do i . org/10.1016/ j.paid.2016.06.057

Schütz, F. F., Sarriera, J., Bedin, L., \& Montserrat, C. (2015). Subjective well-being of children in residential care centers: Comparison between children in institutional care and children living with 
their families. Psicoperspectivas, 14(1), 19-30. https://doi.org/10.5027/ PSICOPERSPECTIVAS-VOL14-ISSUE1FULLTEXT-517

Septiani, A. R. (2019). Laporan Program Pengalaman Lapangan (PPL) bidang psikologi klinis di lembaga pembinaan khusus anak [Tidak Diterbitkan]. Bandung.

Setyawan, D. (2017). KPAI: Ada 3849 pengaduan kasus anak pada tahun 2017. https://www.kpai.go.id/berita/kpaiada-3849-pengaduan-kasus-anak-padatahun-2017

Sholichatun, Y. (2011). Stres dan strategi koping pada anak didik di lembaga pemasyarakatan anak. Psikoislamika Jurnal Psikologi Islam, 8(1), 23 - 42. https://doi.org/10.18860/ psi.v0i1.1544

Tampubolon, E. L. (2017). Efektivitas pembinaan narapidana anak di Lembaga Pembinaan Khusus Anak (LPKA) Pekanbaru. Jom VISIP, 4(1), 1 - 14. https:/ /jom.unri.ac.id/index.php/JOMFSIP/ article/view/12732

Teall, T., Barrera, M., Barr, R., Silva, M., \& Greenberg, M. (2013). Psychological resilience in adolescent and young adult survivors of lower extremity bone tumors. Pediatric Blood \& Cancer, 60(7), 1223-1230. https://doi.org/10.1002/ pbc. 24441

Tomyn, A., \& Weinberg, M. (2016). Resilience and subjective well-being: A psychometric evaluation in young Australian adults: Resilience and subjective well-being. Australian Psychologist, 53(1), 68-76. https:// doi.org/10.1111/ap.12251
Undang-Undang Nomor 23 tahun 2003 Tentang Perlindungan Anak. Republik Indonesia.

Undang-Undang Nomor 11 tahun 2012 Tentang Sistem Peradilan Anak. Republik Indonesia.

Yildirim, M., \& Belen, H. (2019). The role of resilience in the relationships between externality of happiness and subjective well-being and flourishing: A structural equation model approach. Journal of Positive School Psychology, 3(1), 62-76. https: / / www.journalppw.com / index.php/JPPW/article/view/85

Yulianto, \& Ernis, Y. (2016). Lembaga pembinaan khusus anak dalam perspektif sistem peradilan pidana anak. Pohon Cahaya.

Yuniasanti, R., \& Sahrah, A. (2018). Subjective well being measurement based on cognitive components of prisoners at the penitentiary class II A Wirogunan Yogyakarta. Proceeding International Conference on Cross Curtural Understanding, 85-92. http:// lppm.mercubuana-yogya.ac.id/wpcontent/uploads/2017/05/B-18.pdf

Zubair, A., Kamal, A., \& Artemeva, V. (2018). Mindfulness and resilience as predictors of subjective well-being among university students: A cross cultural perspective. Journal of Behavioural Sciences, 28(2), 1-19. http://pu.edu.pk/ images/journal/doap/PDF-FILES/ 01_v28_2_18.pdf

Received 18 September 2020

Revised 17 December 2020 Accepted 5 January 2021 